\title{
Effect of Gas Composition on the NOx Conversion Chemistry in a Plasma
}

\author{
C.R. McLarnon \\ B.M Penetrante
}

This paper was prepared for submittal to the 1998 Society of Automotive Engineers

Fall Fuels and Lubricants Meeting

San Francisco, $\mathrm{CA}$

October 19-22, 1998

August 24, 1998

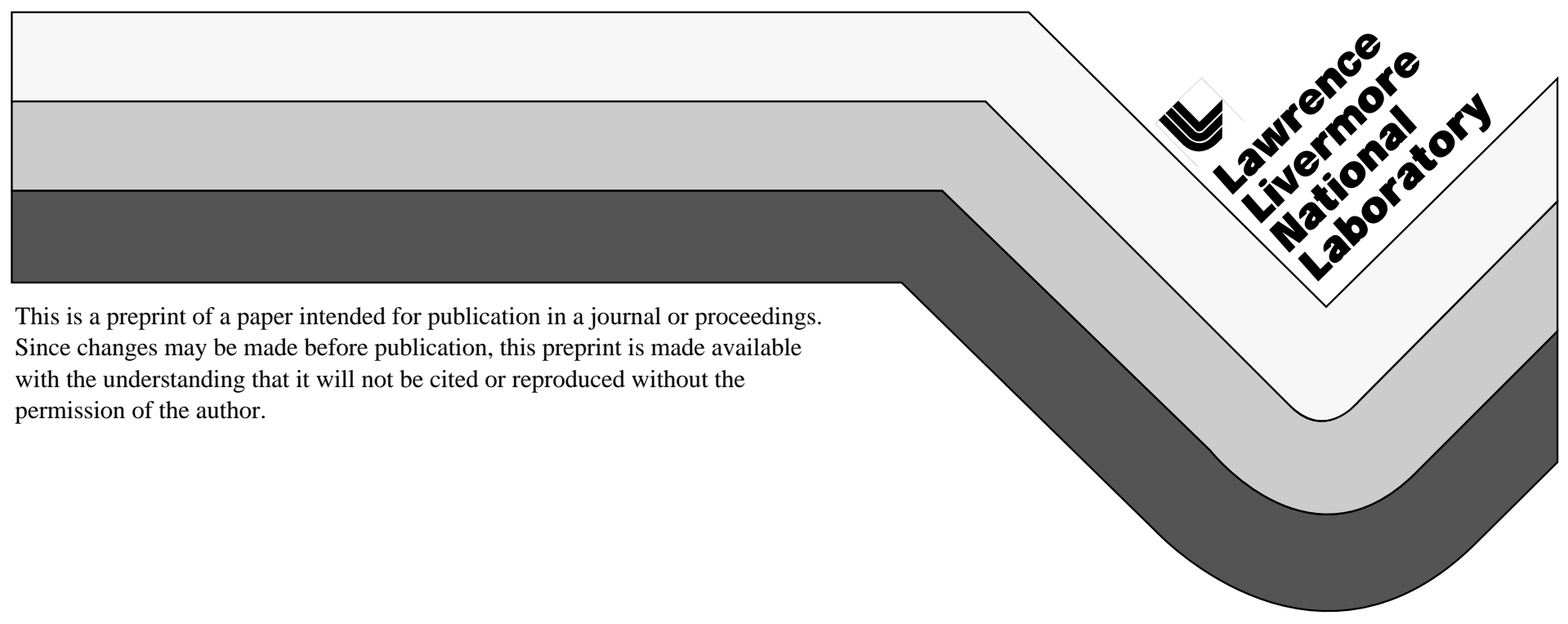




\section{DISCLAIMER}

This document was prepared as an account of work sponsored by an agency of the United States Government. Neither the United States Government nor the University of California nor any of their employees, makes any warranty, express or implied, or assumes any legal liability or responsibility for the accuracy, completeness, or usefulness of any information, apparatus, product, or process

disclosed, or represents that its use would not infringe privately owned rights. Reference herein to any specific commercial product, process, or service by trade name, trademark, manufacturer, or otherwise, does not necessarily constitute or imply its endorsement, recommendation, or favoring by the United States Government or the University of California. The views and opinions of authors expressed herein do not necessarily state or reflect those of the United States Government or the University of California, and shall not be used for advertising or product endorsement purposes. 


\title{
Effect of Gas Composition on the $\mathrm{NO}_{x}$ Conversion Chemistry in a Plasma
}

\author{
Christopher R. McLarnon \\ Zero Emissions Technology \\ Bernie M. Penetrante \\ Lawrence Livermore National Laboratory
}

Copyright (C) 1998 Society of Automotive Engineers, Inc.

\begin{abstract}
Much work has been done on the application of plasmas to the treatment of $\mathrm{NO}_{\mathrm{x}}$ from power plants. In power plant applications, the purpose of the plasma is to oxidize $\mathrm{NO}$ to $\mathrm{NO}_{2}$, and eventually to nitric acid. The desired products, in the form of ammonium salts, are then obtained by mixing ammonia with the formed acids. Some form of scrubbing is required to collect the final products. For applications to the treatment of exhausts from cars and trucks, it is very important to make a distinction between NO removal by chemical oxidation and NO removal by chemical reduction. To avoid the need for scrubbing of plasma processing products, the desired method of NO removal is by chemical reduction; i.e. the conversion of $\mathrm{NO}$ to benign gaseous products like $\mathrm{N}_{2}$. This paper will discuss the results of an extensive series of experiments aimed towards understanding the effect of gas composition on the $\mathrm{NO}_{\mathrm{x}}$ conversion chemistry in a plasma. The $\mathrm{NO}_{\mathrm{x}}$ conversion chemistry in the presence of the individual components, such as $\mathrm{N}_{2}, \mathrm{O}_{2}, \mathrm{H}_{2} \mathrm{O}$, and $\mathrm{CO}_{2}$, as well as the mixture of these, will be presented. We will show that, in a leanburn gasoline or diesel engine exhaust, the main effect of the gas-phase reactions in a plasma is the oxidation of $\mathrm{NO}$ to $\mathrm{NO}_{2}$ and nitric acid. To implement the reduction of $\mathrm{NO}_{\mathrm{x}}$ to $\mathrm{N}_{2}$ in the highly oxidizing environment of a lean-burn engine exhaust, it will be necessary to prevent the formation of acid products and combine the plasma with another process that can chemically reduce $\mathrm{NO}_{2}$ to $\mathrm{N}_{2}$.
\end{abstract}

\section{INTRODUCTION}

A non-thermal plasma is an electrically energized gas like that in a fluorescent lamp. The plasma is nonthermal because the average kinetic energy of the electrons is much higher than that of the gas molecules.

Dissociation and ionization of molecules due to collisions with the energetic electrons create a mix of reactive species that permits unique and diverse chemical reactions to be possible even at relatively low gas temperatures. Non-thermal plasma techniques could presumably initiate $\mathrm{NO}_{X}$ reduction chemistry similar to those of thermal or catalytic deNO $\mathrm{N}_{\mathrm{x}}$ methods. This has prompted a number of laboratories to investigate the application of plasmas to the abatement of $\mathrm{NO}_{\mathrm{X}}[1,2]$.

The application of non-thermal plasmas to the treatment of power plant flue gases has been studied extensively $[1,2]$. In this application the plasma is used to oxidize $\mathrm{NO}$ to $\mathrm{NO}_{2}$, and eventually to nitric acid. The desired product, in the form of ammonium nitrate, is obtained by adding ammonia to the exhaust. Some form of scrubbing is required to collect the final product.

Recently there has been a growing interest in the application of non-thermal plasmas to the removal of $\mathrm{NO}_{x}$ in lean-burn gasoline and diesel engine exhausts [3-5]. These exhausts contain high concentrations of oxygen, rendering conventional catalytic converters ineffective for the treatment of $\mathrm{NO}_{x}$. A critical issue in the application of plasma-based methods to cars and trucks is whether the NO is removed by reduction to benign gases such as $\mathrm{N}_{2}$, or by oxidation to $\mathrm{NO}_{2}$ and nitric acid. To avoid the need for scrubbing of process products, the desired method of $\mathrm{NO}$ removal is by chemical reduction to $\mathrm{N}_{2}$.

This paper will discuss the results of an extensive series of experiments aimed towards understanding the effect of gas composition on the $\mathrm{NO}_{\mathrm{x}}$ conversion chemistry in a plasma. The $\mathrm{NO}_{x}$ conversion chemistry in the presence of the individual components, such as $\mathrm{N}_{2}, \mathrm{O}_{2}, \mathrm{H}_{2} \mathrm{O}$, and $\mathrm{CO}_{2}$, as well as the mixture of these, will be presented. We will show that, in a lean-burn gasoline or diesel engine exhaust, the main effect of the gas-phase reactions in a plasma is the oxidation of $\mathrm{NO}$ to $\mathrm{NO}_{2}$ and nitric acid. To implement the reduction of $\mathrm{NO}_{x}$ to $\mathrm{N}_{2}$ in the highly oxidizing environment of a lean-burn engine exhaust, it will be necessary to prevent the formation of 
acid products and combine the plasma with a heterogeneous process that can chemically reduce $\mathrm{NO}_{2}$ to $\mathrm{N}_{2}$. As shown in another paper, the selective partial oxidation of $\mathrm{NO}$ to $\mathrm{NO}_{2}$ in a plasma can be utilized to enhance the reduction of $\mathrm{NO}_{x}$ to $\mathrm{N}_{2}$ by an SCR catalyst [6].

\section{EXPERIMENT}

PLASMA REACTOR - The plasma reactor used in the experiments reported here is commonly referred to as a dielectric-barrier discharge reactor. The reactor geometry was one of concentric cylinders. The center and outer cylinders were a solid stainless steel rod and stainless steel tube. A high voltage AC power was applied between the electrodes, with the outer electrode tube at ground potential. Various diameter center electrodes were used, ranging from $0.1 \mathrm{~mm}$ to $4 \mathrm{~mm}$. The inner diameter of the outer electrode tube ranged from $22 \mathrm{~mm}$ to $25 \mathrm{~mm}$. Dielectric barriers made of quartz were placed adjacent to the center and outer electrodes. One was used to cover the inner electrode and the other was used to cover the inside of the outer electrode. The length of the plasma reactor tube was $30.5 \mathrm{~cm}$. The discharge plasma region could be made shorter than the tube by limiting the length of the center electrode inside the center dielectric barrier, which ran the full length of the reactor and provided mechanical support for the electrode. A sketch of the plasma reactor is shown in Figure 1.

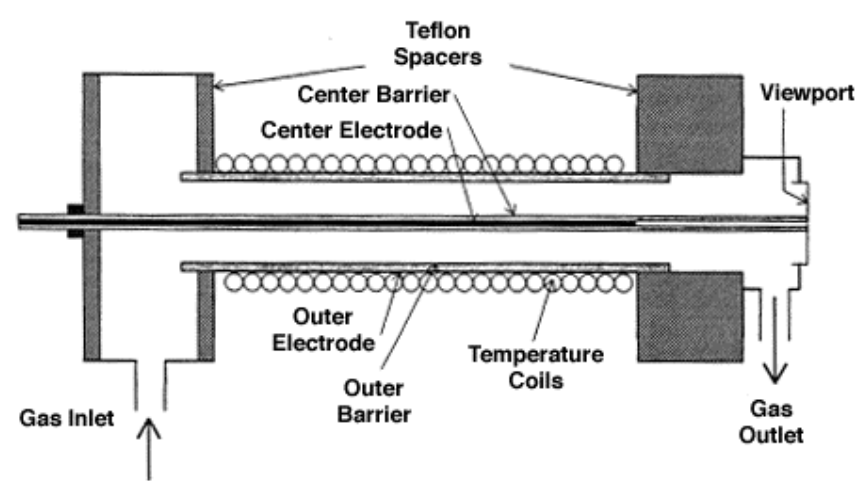

Figure 1. Sketch of the dielectric-barrier discharge reactor used in this study.

Gas entered the inlet plenum of the reactor and travelled axially along the center electrode, exiting through the outlet plenum. A viewport was installed in the exit plenum in line with the center electrode to observe the discharge plasma. The outer stainless steel electrode was wrapped with copper tubing fed by a constant temperature bath for temperature control. Also, the entire reactor could be contained in an oven which could be heated to $100 \mathrm{C}$ to prevent condensation in either the inlet or outlet plenum.

POWER SUPPLY - High voltage AC power was supplied to the plasma reactor. A Powertron 500S variable voltage $(0-120 \mathrm{~V})$, variable frequency $(20-20,000 \mathrm{~Hz})$ power supply was used to power a Neeltran high voltage transformer. The transformer was rated at a primary voltage of $120 \mathrm{~V}$, a secondary voltage of $25 \mathrm{kV}$ and a power limit of $0.5 \mathrm{KVA}$. In parallel with the high voltage transformer was a set of inductors to tune the circuit to the power supply. The inductors, individually ranging from 10 to $25 \mathrm{mH}$, were arranged in series-parallel configurations to reduce the reactive current draw on the power supply. This was necessary because the reactor appeared to the power supply as a cylindrical capacitor with its capacitance dependent upon the reactor length, electrode spacing, size and type of dielectric barriers, and amount and type of packing used, if any. The impedance seen by the power supply, which was dependent on the frequency of the applied voltage, was the reactor impedance multiplied by the square of the windings ratio of the high voltage transformer.

POWER MEASUREMENT - High voltage supplied to the reactor was measured using a Tektronix P6015 high voltage probe (1000x) in series with a Tektronix P6109 probe (10x), effectively dividing the voltage by a factor of 10,000 . The signal from the probe was fed to a Tektronix 2211 digital oscilloscope sampling at $20 \mathrm{MHz}$. The current in the secondary circuit of the high voltage transformer was measured using a series resistor and a Tektronix P6027 (1x) probe. The resistors used varied from 25 to 50 ohms. This signal was fed to the oscilloscope. Power consumption in the reactor (power consumed by the discharge plasma) was measured using the voltage and current traces recorded and stored by the oscilloscope [7]. Digital storage in the oscilloscope was done using an 8 bit analog to digital converter for voltage measurements. 4000 samples per channel were recorded by the oscilloscope. A computer program read the values recorded by the oscilloscope, convert them to the proper units based on the oscilloscope settings and series resistance value, and calculate the power input to the reactor.

To characterize the electrical energy consumption of the plasma process, the composition of the effluent gas was recorded as a function of the input energy density. The input energy density, in units of Joules per standard liter $(\mathrm{J} / \mathrm{L})$, is the ratio of the power (delivered to the plasma) to gas flow rate at standard conditions $\left(25^{\circ} \mathrm{C}\right.$ and $1 \mathrm{~atm}$

GAS SUPPLY - The gas mixture entering the plasma reactor was produced using cylinders of $\mathrm{N}_{2}, \mathrm{O}_{2}, \mathrm{CO}_{2}$ and $\mathrm{NO}$, as shown in Figure 2. $\mathrm{H}_{2} \mathrm{O}$ was introduced to the system by passing the $\mathrm{N}_{2}$ stream through a stainless steel bubbler containing $\mathrm{H}_{2} \mathrm{O}$. The bubbler was heated 


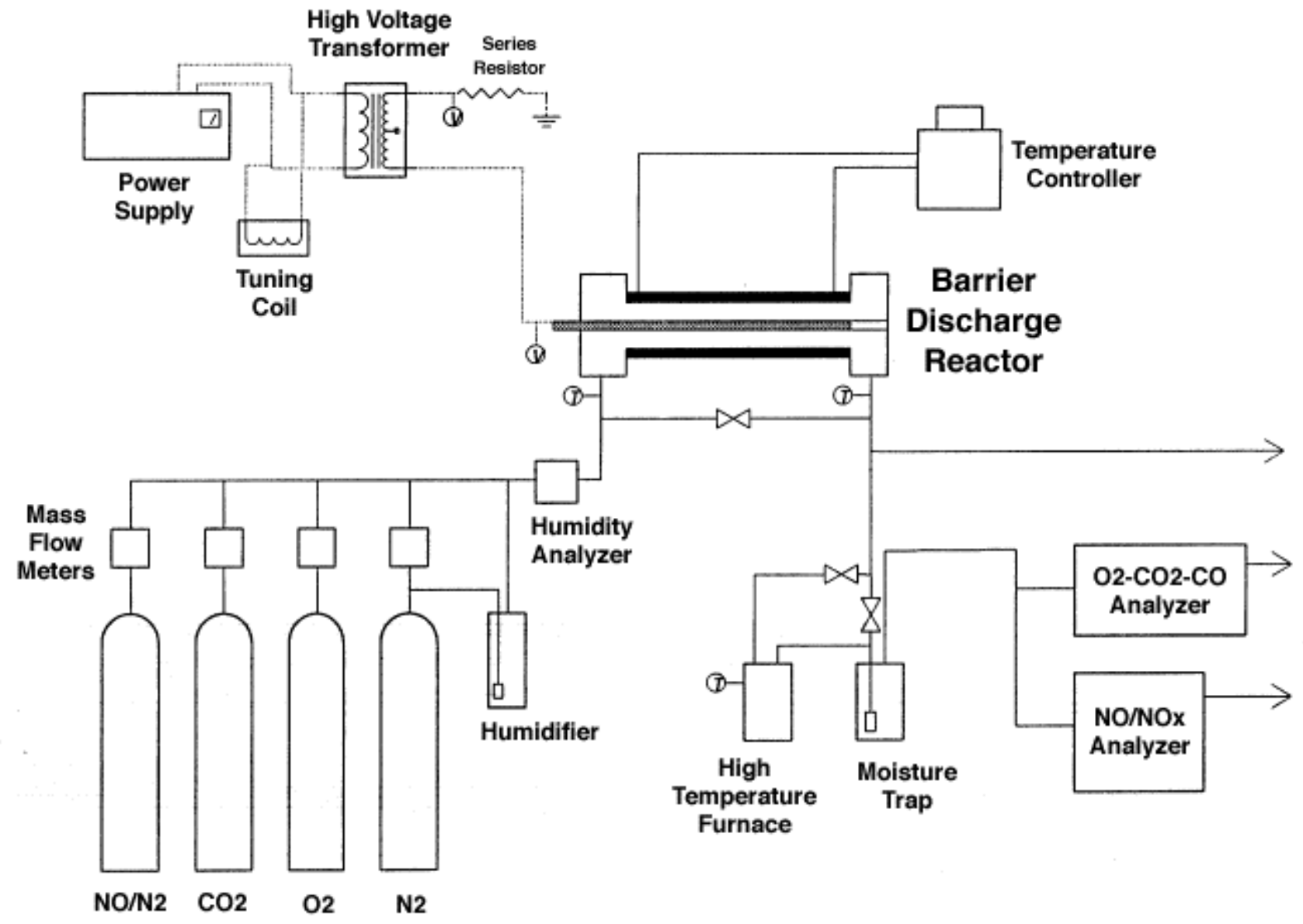

Figure 2. Schematic diagram of the experimental setup and instrumentation.

to vary the moisture content of the $\mathrm{N}_{2}$ stream. Gas flow lines leading to and from the reactor were also heated to prevent condensation of $\mathrm{H}_{2} \mathrm{O}$. Mass flow meters were used to measure the flowrates of dry gases from each of the cylinders.

The tubing used throughout the system was either stainless steel or Teflon, with the exception of the $\mathrm{N}_{2}, \mathrm{O}_{2}$ and $\mathrm{CO}_{2}$ supply lines to the mass flow meters, where Tygon tubing was employed. Teflon and stainless steel minimized the adsorption on the walls of nitric oxide or products of the plasma reactions. Ungrounded, type $\mathrm{K}$ thermocouples were installed at the inlet and outlet of the reactor to measure the temperature of the gas entering and leaving the reactor.

$\mathrm{NO} / \mathrm{NO}_{\mathrm{X}}$ ANALYSIS - A Thermo-Electron model $10 \mathrm{~A} / \mathrm{R}$ chemiluminescent $\mathrm{NO}_{x}$ analyzer was used to measure the concentration of oxides of nitrogen in the gas stream entering or exiting from the reactor. The difference between $\mathrm{NO}$ and $\mathrm{NO}_{x}$ readings was taken to be $\mathrm{NO}_{2}$.
$\mathrm{N}_{2} \mathrm{O}$, a possible product in plasma processing of $\mathrm{NO}$, could not be detected by the NOx analyzer. A HewlettPackard 5890 Series II gas chromatograph with a thermal conductivity detector was used to determine if $\mathrm{N}_{2} \mathrm{O}$ was present in the reactor exit gas. A 9' by $1 / 8$ " stainless steel column packed with 50/80 mesh Porapak $\mathrm{T}$ was used to separate $\mathrm{N}_{2} \mathrm{O}$ from the other gases in the stream.

$\mathrm{O}_{2}, \mathrm{CO}_{2}$ AND CO ANALYSIS - A Nova model 375 portable combustion analyzer was used to measure the $\mathrm{O}_{2}, \mathrm{CO}_{2}$ and $\mathrm{CO}$ concentrations in the gas stream. The $\mathrm{O}_{2}$ and $\mathrm{CO}$ analyses were performed in the analyzer using electrochemical cells while the $\mathrm{CO}_{2}$ analysis was performed using an infrared cell.

$\mathrm{H}_{2} \mathrm{O}$ MEASUREMENT - An EG\&G Environmental model 911 digital humidity analyzer was used to measure the $\mathrm{H}_{2} \mathrm{O}$ content of the inlet gas. The instrument used the chilled mirror dew point condensation principle. It was installed upstream of the reactor to prevent condensation of acids on the mirror surfaces. 
NITRIC ACID MEASUREMENT - To measure the nitric acid the sample gas was passed through a $1 \mathrm{~m}$ length of $3.2 \mathrm{~mm}$ stainless steel tubing enclosed in a high temperature furnace at $700 \mathrm{C}$. The nitric acid and $\mathrm{NO}_{2}$ present in the gas stream was completely decomposed and reduced to NO. The gas was then delivered to the $\mathrm{NO}_{\mathrm{x}}$ analyzer where the NO concentration was measured. This concentration was then compared to the $\mathrm{NO}_{\mathrm{x}}$ concentration of a sample stream that was not passed through the high temperature furnace. The difference was taken to be $\mathrm{HNO}_{3}$. Tests performed on nitric acid laden gas streams, prepared by introducing acid into the gas stream, showed that the temperature and residence time of the gas in the high temperature furnace was sufficient to completely decomposed all of the acid to NO.

\section{PLASMA CHEMISTRY ANALYSIS}

The intent in using a non-thermal plasma is to selectively transfer the input electrical energy to the electrons. In the kinetic analysis of non-thermal plasma methods, the first step is to understand the deposition of energy into contaminated air. This is controlled primarily by the major components, such as $\mathrm{N}_{2}, \mathrm{O}_{2}, \mathrm{CO}_{2}$ and $\mathrm{H}_{2} \mathrm{O}$.

The most useful energy deposition into $\mathrm{N}_{2}$ and $\mathrm{O}_{2}$ is usually associated with the production of $\mathrm{N}$ and $\mathrm{O}$ atoms through electron impact dissociation, and ionization, producing either atomic or molecular ions. One must also account for the creation of metastables, especially in the dissociated atoms $\mathrm{O}$ and $\mathrm{N}$. For example, the reaction rates for the metastable $O\left({ }^{1} \mathrm{D}\right)$ are almost always larger than those for the corresponding reactions with ground state $\mathrm{O}\left({ }^{3} \mathrm{P}\right)$. This can enhance both desired and undesired reactions.

The electron energy distribution in a plasma reactor is important because it determines the types of radicals produced in the plasma and the input electrical energy required to produce those radicals. In discharge processing, the rate coefficients for electron-impact dissociation reactions strongly depend on the electron mean energy in the discharge plasma.

Most of the species responsible for the chemical processing are generated during the main current flow (at which time the microdischarge channels have already been formed). The electrons acquire a drift velocity, $v_{d}$, and an average energy corresponding to an effective $E / n$, i.e., the value of the electric field $E$ divided by the total gas density $n$.

The efficiency for a particular electron-impact process can be expressed in terms of the G-value (number of reactions per $100 \mathrm{eV}$ of input energy) defined as

$$
\text { G-value }=100 \mathrm{k} /\left(\mathrm{v}_{\mathrm{d}} \mathrm{E} / \mathrm{n}\right)
$$

where $k$ is the rate coefficient $\left(\mathrm{cm}^{3} / \mathrm{molec}^{-s}\right)$. The quantity $\mathrm{knn}_{\mathrm{e}}$ represents the number of reactions in a unit volume per unit time, where $n_{e}$ is the electron density. The quantity $v_{d} E n_{e}$ represents the amount of energy expended by the electrons in a unit volume per unit time. The G-value is the ratio of the number of reactions to the amount of energy expended by the electrons.

To calculate the G-values, we used the Boltzmann code ELENDIF [8] to calculate electron energy deposition. ELENDIF uses as input the specified gas composition and the electron-molecule collision cross sections.

The chemical kinetics describing the subsequent interaction of the ions and radicals with the exhaust gas was then studied using CHEMKIN-II [9]. Non-equilibrium plasma chemistry is handled by specifying G-values for forward reactions involving electron-impact dissociation and ionization of the various molecules.

The chemical kinetics analysis shows that the $\mathrm{NO}_{\mathrm{x}}$ conversion chemistry is determined mainly by uncharged species. In electrical discharge plasmas, the G-values for production of charged species is very small compared, for example, to that for production of $\mathrm{O}$ radicals. The charged species therefore do not contribute significantly to the $\mathrm{NO}_{\mathrm{x}}$ conversion chemistry.

\section{CHEMICAL REDUCTION IN N2}

Figure 3 shows the result of plasma processing of 500 ppm $\mathrm{NO}$ in $\mathrm{N}_{2}$ at $25^{\circ} \mathrm{C}$. In the absence of $\mathrm{O}_{2}$, the $\mathrm{NO}$ can be chemically reduced to $\mathrm{N}_{2}$. Electron-impact dissociation of $\mathrm{N}_{2}$ produces atomic nitrogen species:

$$
\begin{aligned}
& e+N_{2} \rightarrow e+N\left({ }^{4} S\right)+N\left({ }^{4} S\right) \\
& e+N_{2} \rightarrow e+N\left({ }^{4} S\right)+N\left({ }^{2} D\right)
\end{aligned}
$$

where $\mathrm{N}\left({ }^{4} \mathrm{~S}\right)$ and $\mathrm{N}\left({ }^{2} \mathrm{D}\right)$ are ground-state and metastable excited-state nitrogen atoms, respectively. With very small amounts of $\mathrm{O}_{2}$, the excited state $\mathrm{N}\left({ }^{2} \mathrm{D}\right)$ is quenched by $\mathrm{N}_{2}$ to the ground state $\mathrm{N}\left({ }^{4} S\right)$. Chemical reduction of $\mathrm{NO}$ is then accomplished via

$$
\mathrm{N}\left({ }^{4} \mathrm{~S}\right)+\mathrm{NO} \rightarrow \mathrm{N}_{2}+\mathrm{O}
$$

The $O$ radical resulting from reaction (3) can lead to the oxidation of $\mathrm{NO}$ to $\mathrm{NO}_{2}$. However, the amount of $\mathrm{O}$ radicals is, at most, equal to the total number of $\mathrm{N}\left({ }^{4} \mathrm{~S}\right)$ produced in the plasma. Under this condition, most of the NO react with $\mathrm{N}\left({ }^{4} \mathrm{~S}\right)$ and only a very small amount of $\mathrm{NO}_{2}$ is produced.

The electrical energy density input is a parameter commonly used to evaluate the $\mathrm{NO}_{\mathrm{x}}$ conversion efficiency in the plasma. An engine with a load of 100 kW and an exhaust gas flow rate of 7600 liters per 
minute $(\mathrm{L} / \mathrm{min})$ has an energy density output of $\left(10^{5} \mathrm{~J} / \mathrm{s}\right)$ / ( $(127 \mathrm{~L} / \mathrm{s})=790 \mathrm{~J} / \mathrm{L}$. For example, suppose a plasma reactor consumes $20 \mathrm{~J} / \mathrm{L}$ to achieve a certain amount of $\mathrm{NO}_{\mathrm{x}}$ reduction. This means that the plasma reactor will consume $100 \times(20 \mathrm{~J} / \mathrm{L}) /(790 \mathrm{~J} / \mathrm{L})=2.5 \%$ of the engine energy output.

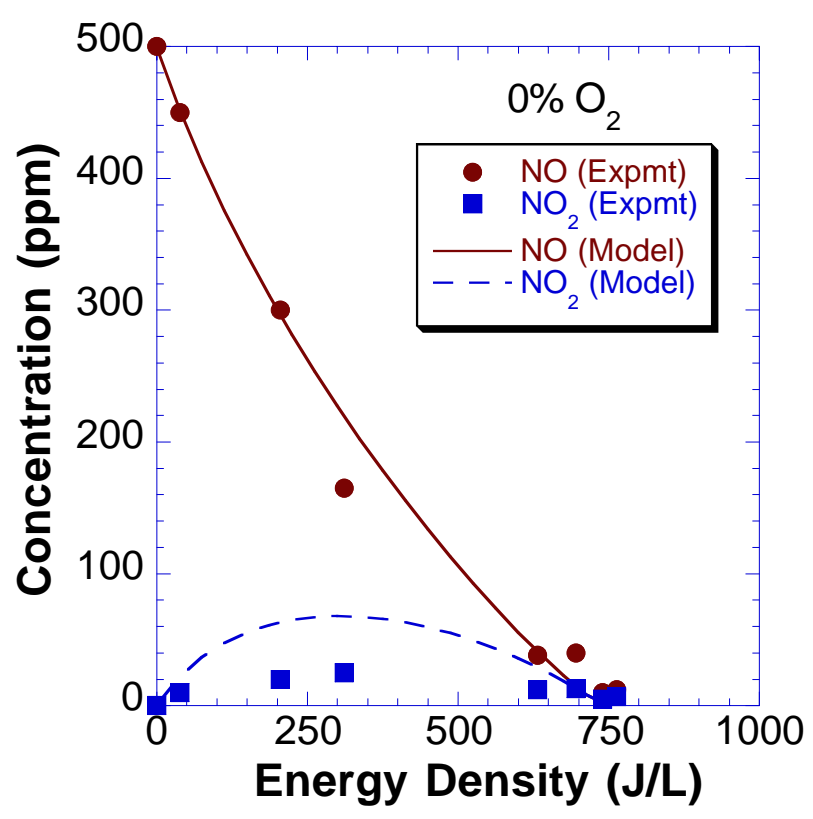

Figure 3. Plasma processing of $500 \mathrm{ppm} \mathrm{NO}$ in $\mathrm{N}_{2}$ at $25^{\circ} \mathrm{C}$.

The energy density required to achieve a certain amount of $\mathrm{NO}_{X}$ conversion is determined largely by the G-value for electron-impact reactions. For the case of $\mathrm{NO}$ in $\mathrm{N}_{2}$, the energy density required for chemical reduction of $\mathrm{NO}$ to $\mathrm{N}_{2}$ is determined by the G-value for electron-impact dissociation of $\mathrm{N}_{2}$ (reaction 2), as discussed in more detail by Penetrante et al. [10]. The energy densities shown in Figure 1 are extremely large compared to what would be acceptable in a typical engine exhaust treatment system. Measurement of $\mathrm{NO}_{x}$ reduction in $\mathrm{N}_{2}$ provides a good way of measuring the $\mathrm{N}$ atom production in the plasma; however, it is clear that production of $\mathrm{N}$ atoms in an electrical discharge plasma may not be a practical method for doing $\mathrm{NO}_{\mathrm{x}}$ reduction.

\section{EFFECT OF $\mathrm{O}_{2}$}

Figures 4-9 show the effect of $\mathrm{O}_{2}$ concentration on the plasma processing of $500 \mathrm{ppm} \mathrm{NO}$ in $\mathrm{O}_{2} / \mathrm{N}_{2}$ mixtures at $25^{\circ} \mathrm{C}$. As the $\mathrm{O}_{2}$ concentration is increased, the amount of $\mathrm{NO}$ that is chemically reduced to $\mathrm{N}_{2}$ decreases and the amount of $\mathrm{NO}$ that is oxidized to $\mathrm{NO}_{2}$ increases.

Electron-impact dissociation of $\mathrm{O}_{2}$ produces $\mathrm{O}$ radicals:

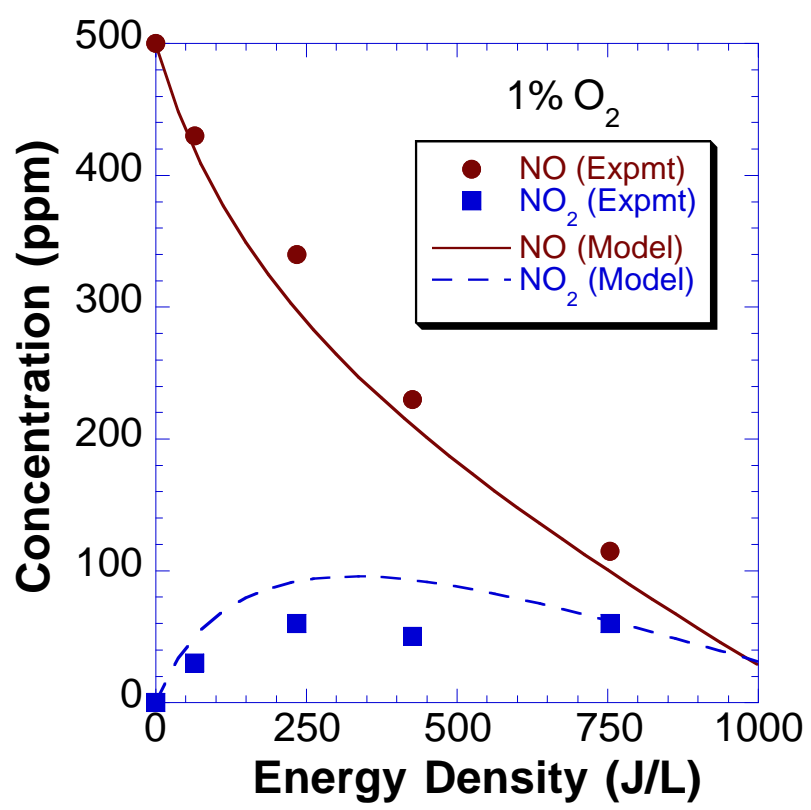

Figure 4. Plasma processing of $500 \mathrm{ppm} \mathrm{NO}$ in $1 \% \mathrm{O}_{2}$, balance $\mathrm{N}_{2}$ at $25^{\circ} \mathrm{C}$.

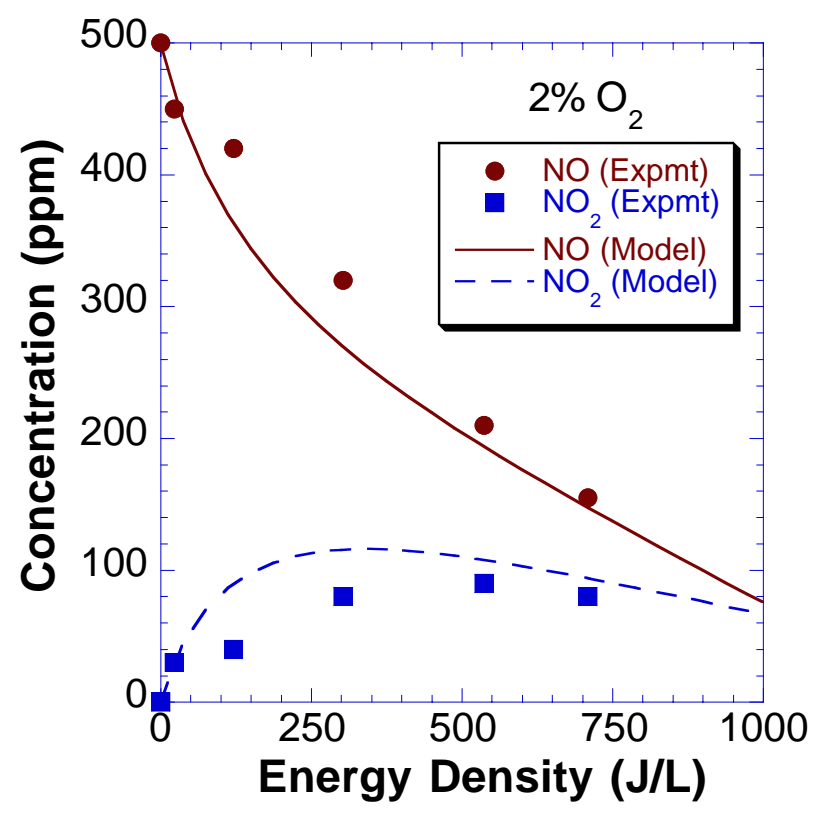

Figure 5. Plasma processing of $500 \mathrm{ppm} \mathrm{NO}$ in $2 \% \mathrm{O}_{2}$, balance $\mathrm{N}_{2}$ at $25^{\circ} \mathrm{C}$.

$$
\begin{aligned}
& e+\mathrm{O}_{2} \rightarrow \mathrm{e}+\mathrm{O}\left({ }^{3} \mathrm{P}\right)+\mathrm{O}\left({ }^{3} \mathrm{P}\right) \\
& \mathrm{e}+\mathrm{O}_{2} \rightarrow \mathrm{e}+\mathrm{O}\left({ }^{3} \mathrm{P}\right)+\mathrm{O}\left({ }^{1} \mathrm{D}\right)
\end{aligned}
$$

where $O\left({ }^{3} P\right)$ and $O\left({ }^{1} D\right)$ are ground-state and metastable excited-state oxygen atoms, respectively. 


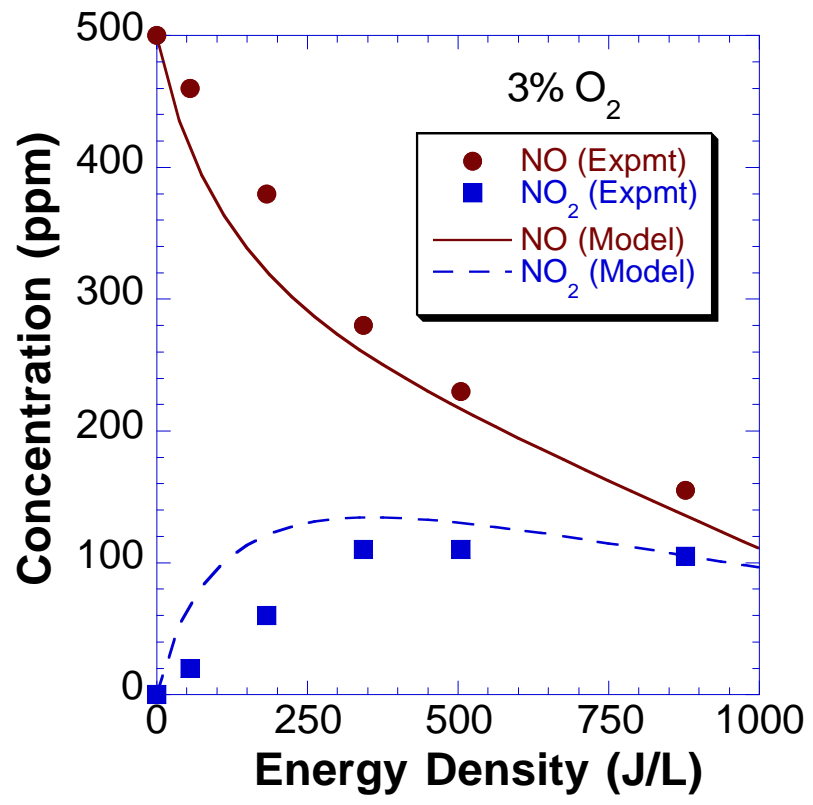

Figure 6. Plasma processing of $500 \mathrm{ppm} \mathrm{NO}$ in $3 \% \mathrm{O}_{2}$, balance $\mathrm{N}_{2}$ at $25^{\circ} \mathrm{C}$.

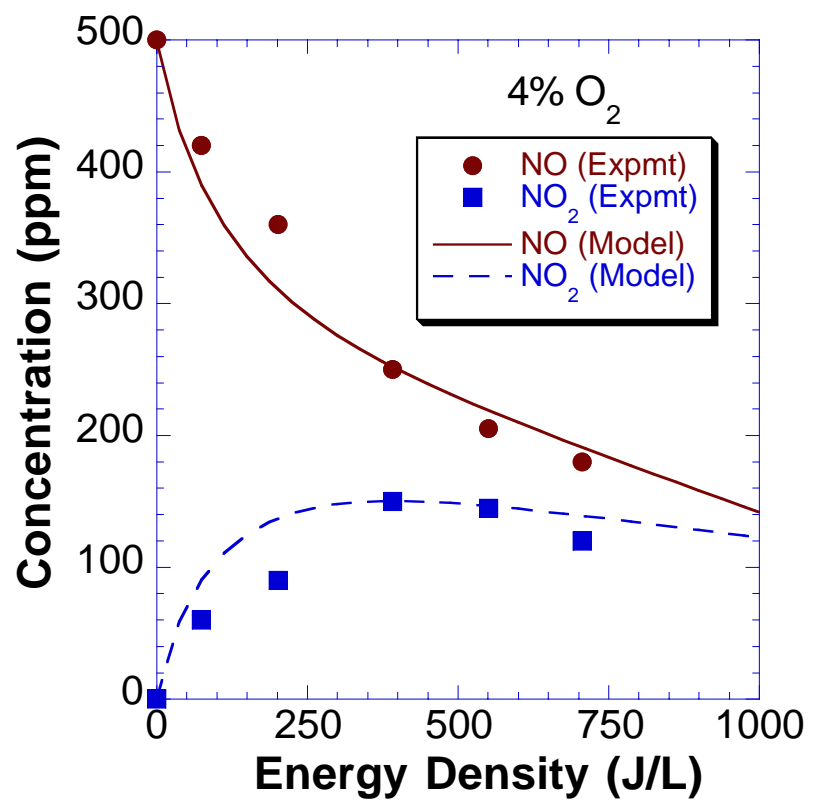

Figure 7. Plasma processing of $500 \mathrm{ppm} \mathrm{NO}$ in $4 \% \mathrm{O}_{2}$, balance $\mathrm{N}_{2}$ at $25^{\circ} \mathrm{C}$.

The G-values for electron-impact dissociation of $\mathrm{O}_{2}$ are shown in Figure 10. Our chemical kinetics analysis indicate an electron mean energy in the plasma of around $3 \mathrm{eV}$.

Figure 11 shows a chemical kinetics analysis of the important reactions during plasma processing of 500 ppm NO in $6 \% \mathrm{O}_{2}$, balance $\mathrm{N}_{2}$, at $25^{\circ} \mathrm{C}$. In the absence

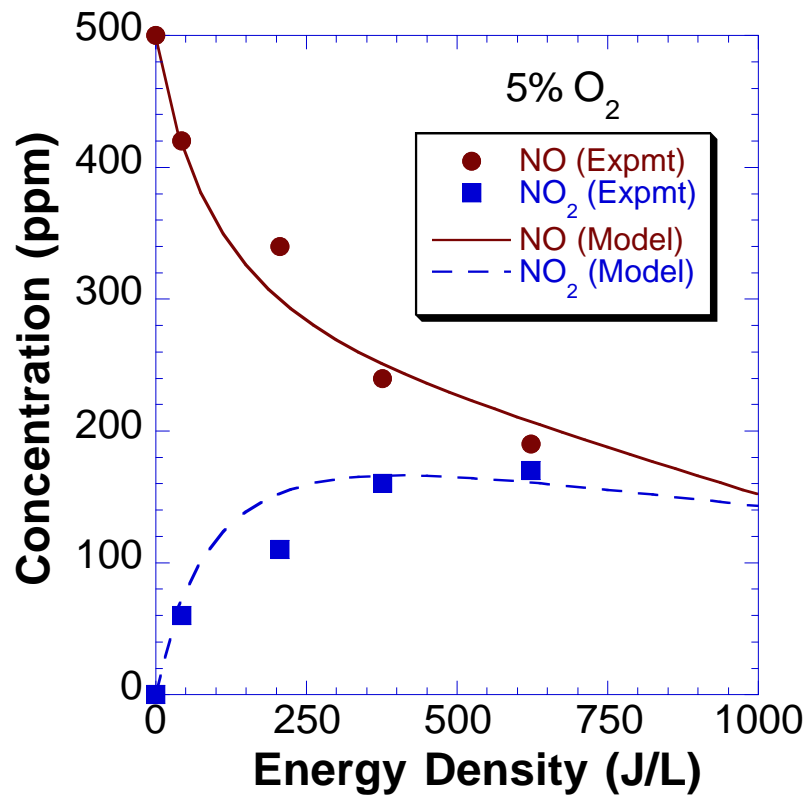

Figure 8. Plasma processing of $500 \mathrm{ppm} \mathrm{NO}$ in $5 \% \mathrm{O}_{2}$, balance $\mathrm{N}_{2}$ at $25^{\circ} \mathrm{C}$.

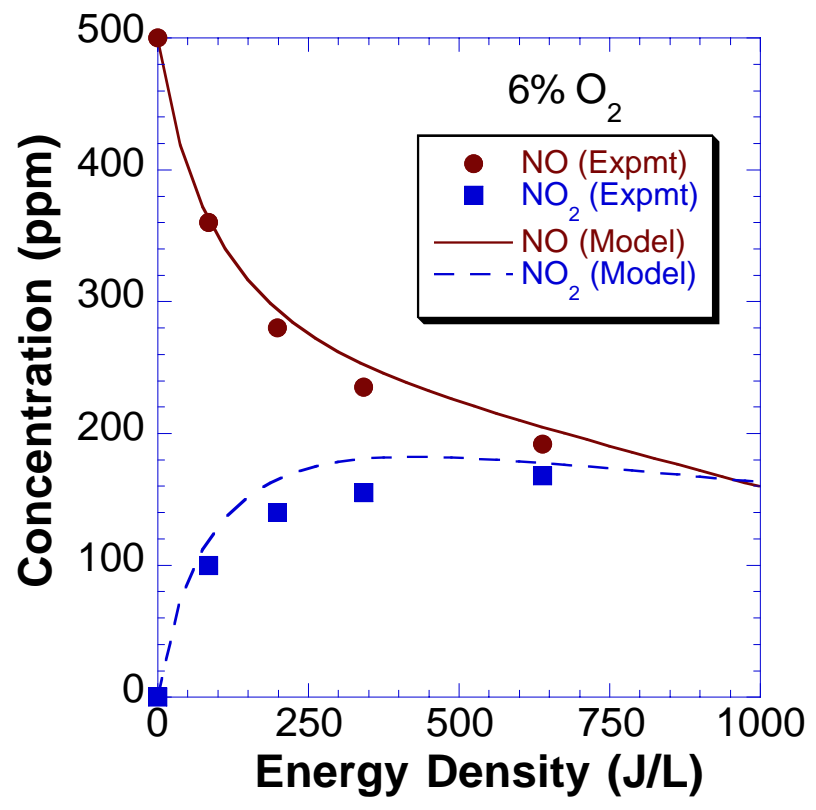

Figure 9. Plasma processing of $500 \mathrm{ppm} \mathrm{NO}$ in $6 \% \mathrm{O}_{2}$, balance $\mathrm{N}_{2}$ at $25^{\circ} \mathrm{C}$.

of $\mathrm{H}_{2} \mathrm{O}$, most of the excited-state $\mathrm{O}\left({ }^{1} \mathrm{D}\right)$ is quenched by $\mathrm{O}_{2}$ to the ground state $\mathrm{O}\left({ }^{3} \mathrm{P}\right)$. At low input energy densities $(<100 \mathrm{~J} / \mathrm{L})$, the oxidation of $\mathrm{NO}$ to $\mathrm{NO}_{2}$ is accomplished mainly via

$$
\mathrm{O}\left({ }^{3} \mathrm{P}\right)+\mathrm{NO}+\mathrm{M} \rightarrow \mathrm{NO}_{2}+\mathrm{M}
$$




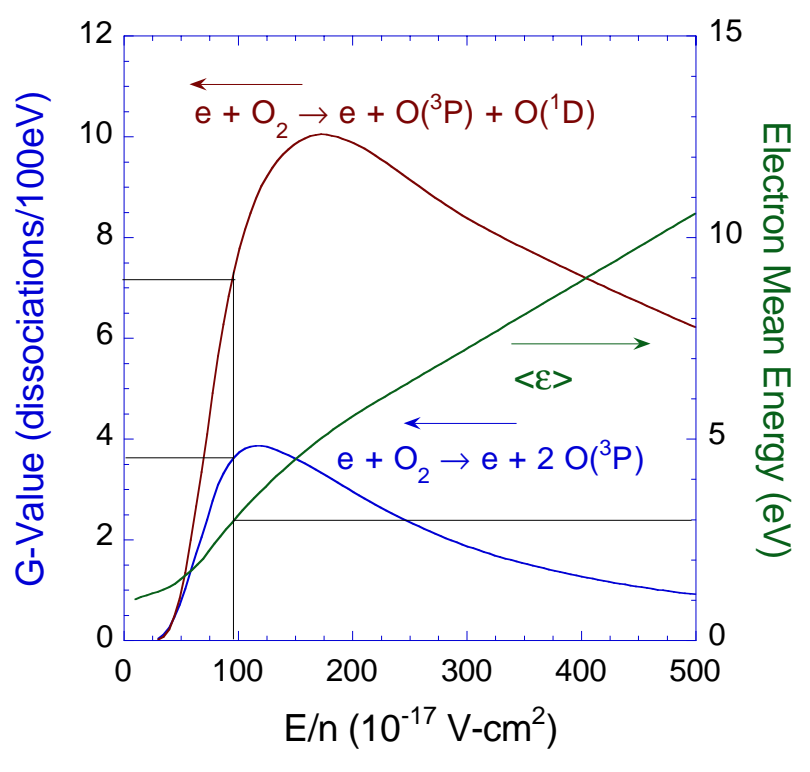

Figure 10. G-values for electron-impact dissociation of $\mathrm{O}_{2}$ in an electrical discharge plasma, shown as a function of effective $E / n$ (electric field divided by the total gas density) and the corresponding electron mean energy. where $\mathrm{M}$ is either $\mathrm{N}_{2}$ or $\mathrm{O}_{2}$. At higher energy densities (> $100 \mathrm{~J} / \mathrm{L}$ ), ozone production becomes significant and the ozone also eventually leads to the oxidation of $\mathrm{NO}$ to $\mathrm{NO}_{2}$ :

$$
\begin{aligned}
& \mathrm{O}+\mathrm{O}_{2}+\mathrm{M} \rightarrow \mathrm{O}_{3}+\mathrm{M} \\
& \mathrm{O}_{3}+\mathrm{NO} \rightarrow \mathrm{NO}_{2}+\mathrm{O}_{2}
\end{aligned}
$$

Figure 12 shows the effect of $\mathrm{O}_{2}$ concentration on the Gvalues for electron-impact dissociation of both $\mathrm{O}_{2}$ and $\mathrm{N}_{2}$. Note that the $\mathrm{G}$-value for $\mathrm{N}_{2}$ dissociation is close to two orders of magnitude less than that for $\mathrm{O}_{2}$ dissociation. Furthermore, the amount of $\mathrm{N}_{2}$ dissociation decreases as the $\mathrm{O}_{2}$ concentration is increased.

Not all of the $\mathrm{O}$ radicals are used in the oxidation of $\mathrm{NO}$ to $\mathrm{NO}_{2}$. A significant amount of the $\mathrm{O}$ radicals reduce $\mathrm{NO}_{2}$ back to $\mathrm{NO}$ :

$$
\mathrm{O}+\mathrm{NO}_{2} \rightarrow \mathrm{NO}+\mathrm{O}_{2}
$$

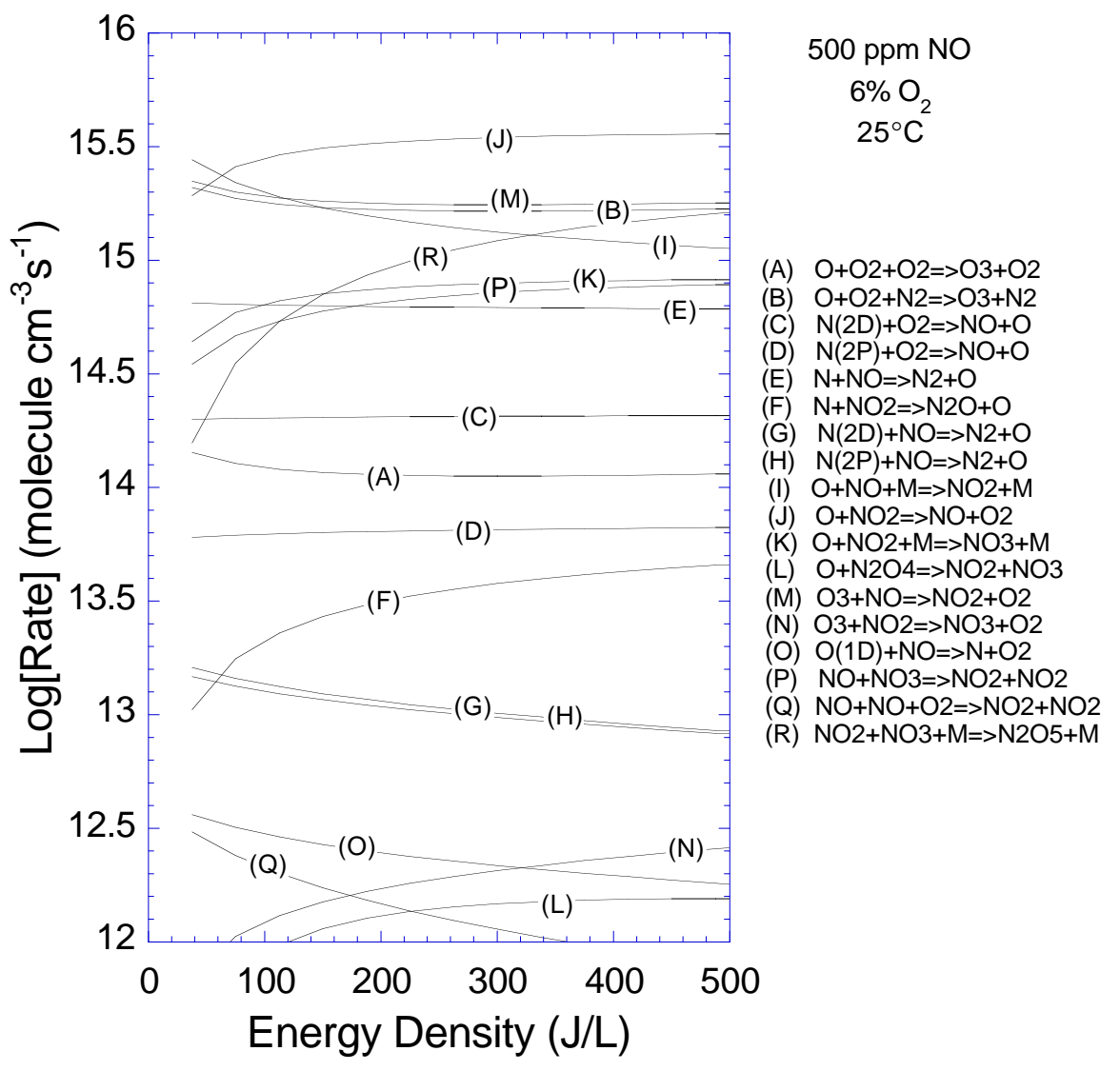

Figure 11. Chemical kinetics analysis of the important reactions during plasma processing of $500 \mathrm{ppm} \mathrm{NO}$ in $6 \% \mathrm{O}_{2}$, balance $\mathrm{N}_{2}$ at $25^{\circ} \mathrm{C}$. 


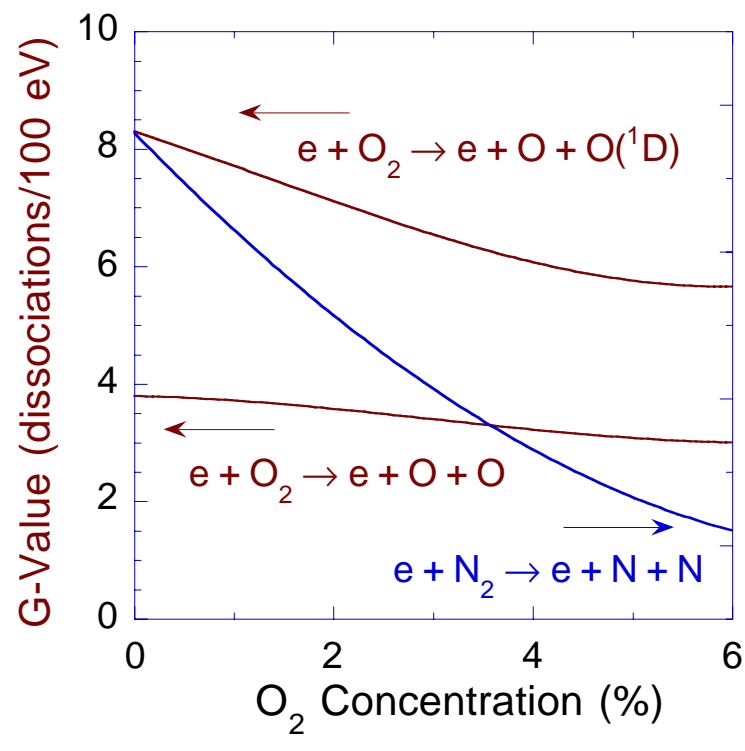

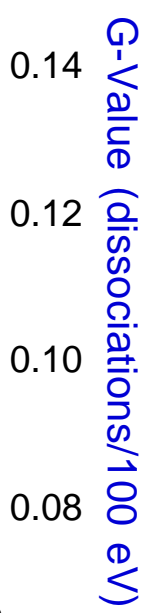

Figure 12. Effect of $\mathrm{O}_{2}$ concentration on the $\mathrm{G}$-values for electron-impact dissociation of $\mathrm{O}_{2}$ and $\mathrm{N}_{2}$ in an electrical discharge plasma.

The backconversion of $\mathrm{NO}_{2}$ to $\mathrm{NO}$ via reaction (7) becomes a limiting factor on the oxidation efficiency at high temperatures. Figures 13 and 14 show the plasma processing of $500 \mathrm{ppm} \mathrm{NO}$ in $6 \% \mathrm{O}_{2}$, balance $\mathrm{N}_{2}$, at $100^{\circ} \mathrm{C}$ and $200^{\circ} \mathrm{C}$, respectively. Figure 15 shows a chemical kinetics analysis of the important reactions during plasma processing at $200^{\circ} \mathrm{C}$. Note the strong competition between oxidation of $\mathrm{NO}$ to $\mathrm{NO}_{2}$ and reduction of $\mathrm{NO}_{2}$ to $\mathrm{NO}$.

\section{EFFECT OF $\mathrm{CO}_{2}$}

Figure 16 shows the plasma processing of $500 \mathrm{ppm} \mathrm{NO}$ in $6 \% \mathrm{O}_{2}$, balance $\mathrm{N}_{2}$, compared to the plasma processing in $10 \% \mathrm{CO}_{2}, 6 \% \mathrm{O}_{2}$, balance $\mathrm{N}_{2}$. Both sets of experiments were done at $25^{\circ} \mathrm{C}$. Note that $\mathrm{CO}_{2}$ has very little effect on the $\mathrm{NO}_{\mathrm{x}}$ conversion chemistry. The dominant reaction remains the oxidation of $\mathrm{NO}$ to $\mathrm{NO}_{2}$. The most important consequence of having $\mathrm{CO}_{2}$ in the plasma is the production of $\mathrm{CO}$.

\section{EFFECT OF $\mathrm{H}_{2} \mathrm{O}$}

Figure 17 shows the plasma processing of $500 \mathrm{ppm} \mathrm{NO}$ in $1 \% \mathrm{H}_{2} \mathrm{O}$, balance $\mathrm{N}_{2}$, at $25^{\circ} \mathrm{C}$. A chemical kinetics analysis of the important reactions under the same condition is shown in Figure 18. The dominant NO conversion is by reduction to $\mathrm{N}_{2}$, reaction (3).

Electron-impact dissociation of $\mathrm{H}_{2} \mathrm{O}$ leads to the production of $\mathrm{H}$ and $\mathrm{OH}$ radicals:

$$
\mathrm{e}+\mathrm{H}_{2} \mathrm{O} \rightarrow \mathrm{e}+\mathrm{H}+\mathrm{OH}
$$

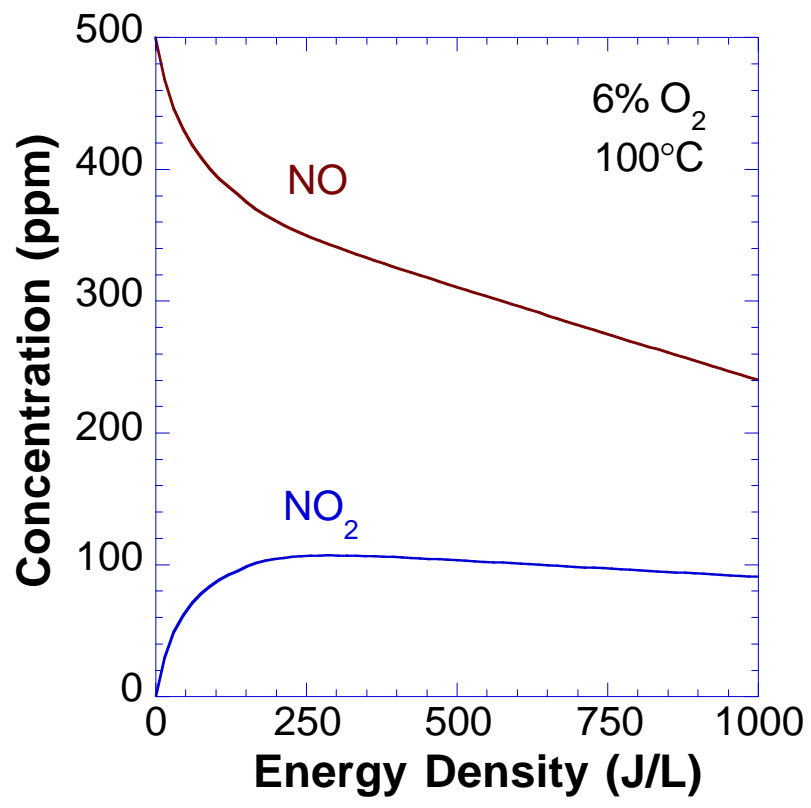

Figure 13. Plasma processing of $500 \mathrm{ppm} \mathrm{NO}$ in $6 \% \mathrm{O}_{2}$, balance $\mathrm{N}_{2}$ at $100^{\circ} \mathrm{C}$. Compare to Figure 9 showing plasma processing of $500 \mathrm{ppm} \mathrm{NO}$ in $6 \% \mathrm{O}_{2}$, balance $\mathrm{N}_{2}$ at $25^{\circ} \mathrm{C}$.

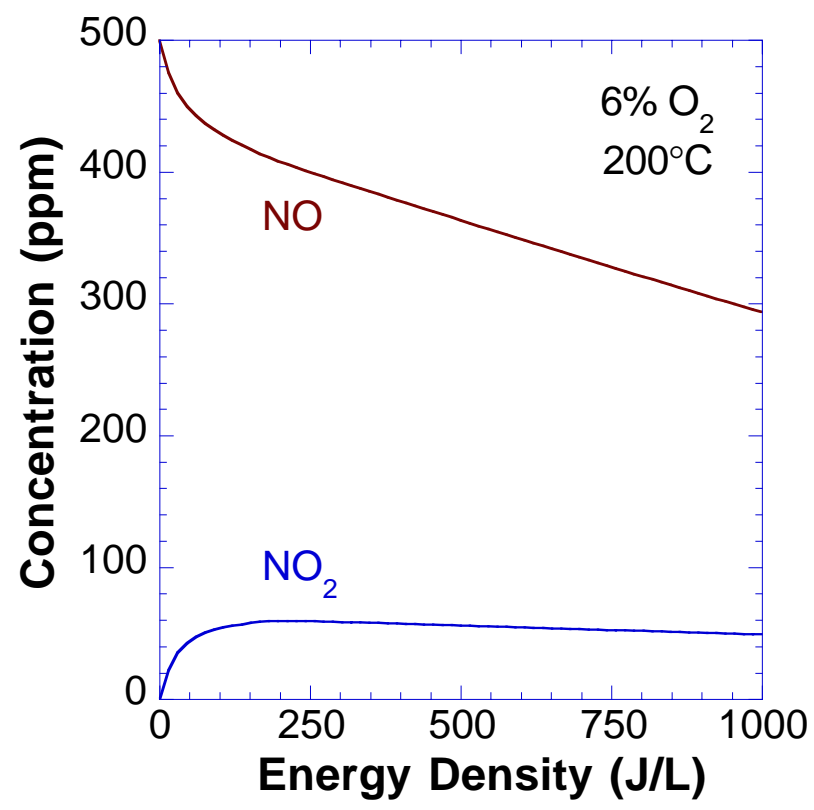

Figure 14. Plasma processing of $500 \mathrm{ppm} \mathrm{NO}$ in $6 \% \mathrm{O}_{2}$, balance $\mathrm{N}_{2}$ at $200^{\circ} \mathrm{C}$. Compare to Figures 9 and 13 showing plasma processing of $500 \mathrm{ppm} \mathrm{NO}$ in $6 \% \mathrm{O}_{2}$, balance $\mathrm{N}_{2}$ at $25^{\circ} \mathrm{C}$ and $100^{\circ} \mathrm{C}$, respectively.

The $\mathrm{OH}$ radical leads to the formation of nitrous acid

$$
\mathrm{OH}+\mathrm{NO}+\mathrm{M} \rightarrow \mathrm{HNO}_{2}+\mathrm{M}
$$




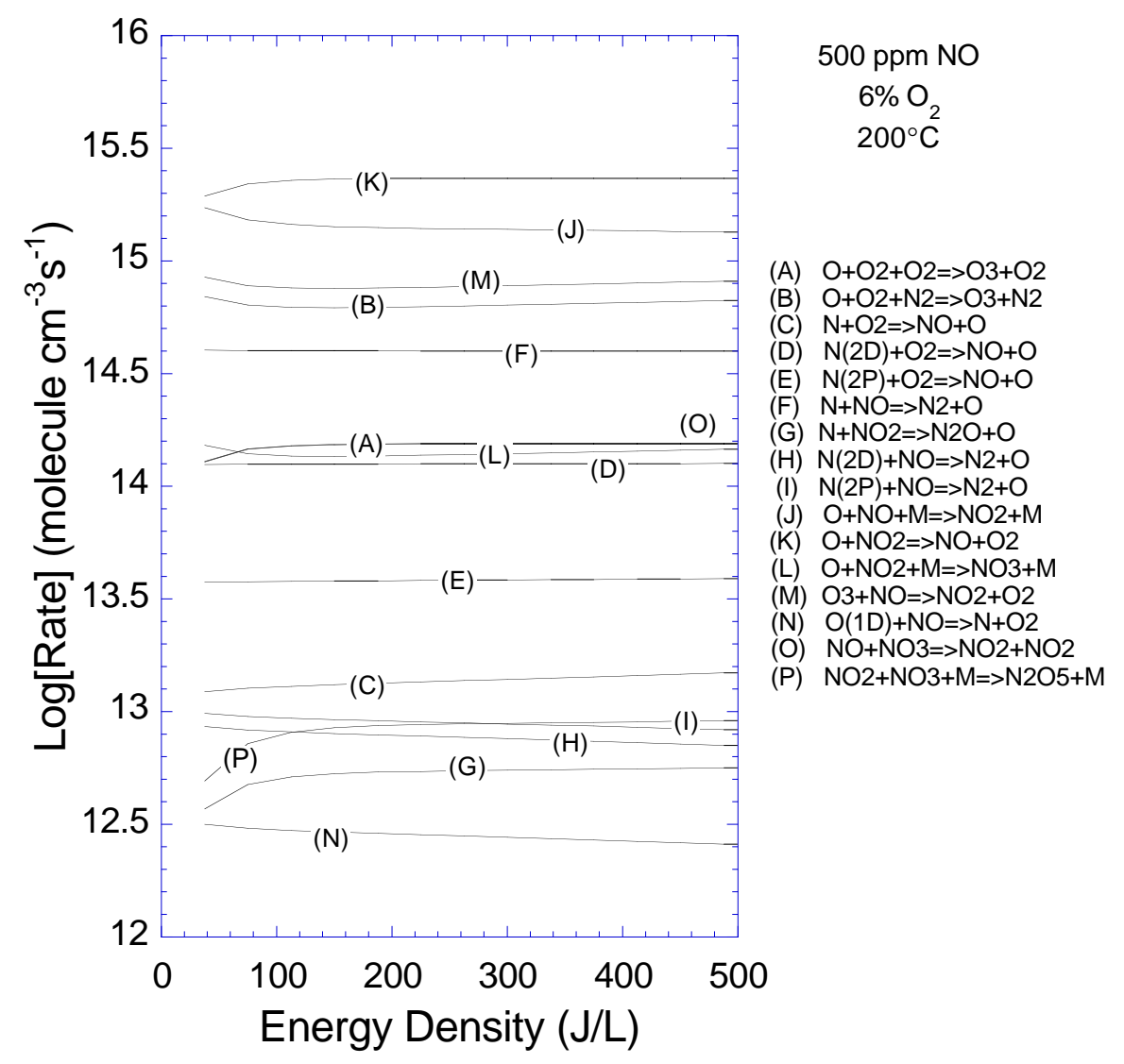

Figure 15. Chemical kinetics analysis of the important reactions during plasma processing of $500 \mathrm{ppm} \mathrm{NO}$ in $6 \% \mathrm{O}_{2}$, balance $\mathrm{N}_{2}$ at $200^{\circ} \mathrm{C}$.

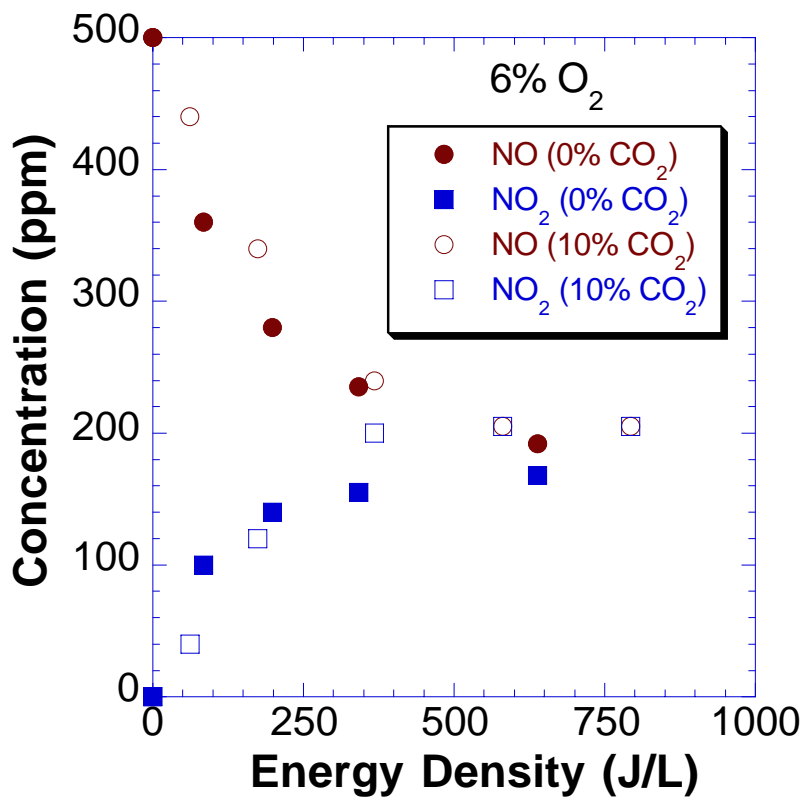

Figure 16. Plasma processing of $500 \mathrm{ppm} \mathrm{NO}$ in $6 \% \mathrm{O}_{2}$, balance $\mathrm{N}_{2}$, compared to plasma processing of $500 \mathrm{ppm}$ $\mathrm{NO}$ in $10 \% \mathrm{CO}_{2}, 6 \% \mathrm{O}_{2}$, balance $\mathrm{N}_{2} .25^{\circ} \mathrm{C}$.

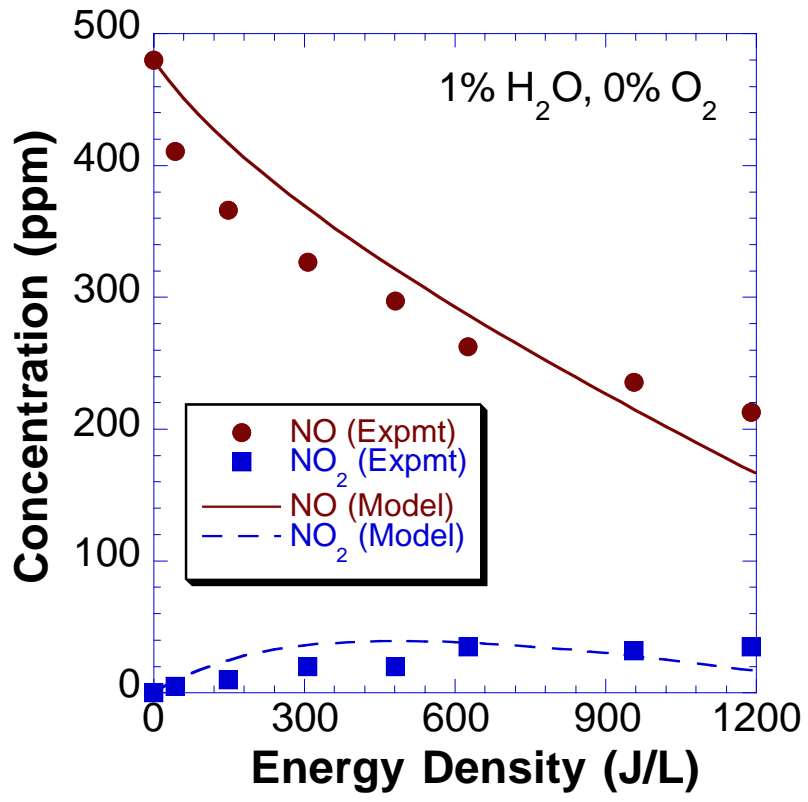

Figure 17. Plasma processing of $500 \mathrm{ppm} \mathrm{NO}$ in $1 \%$ $\mathrm{H}_{2} \mathrm{O}$, balance $\mathrm{N}_{2}$ at $25^{\circ} \mathrm{C}$. 


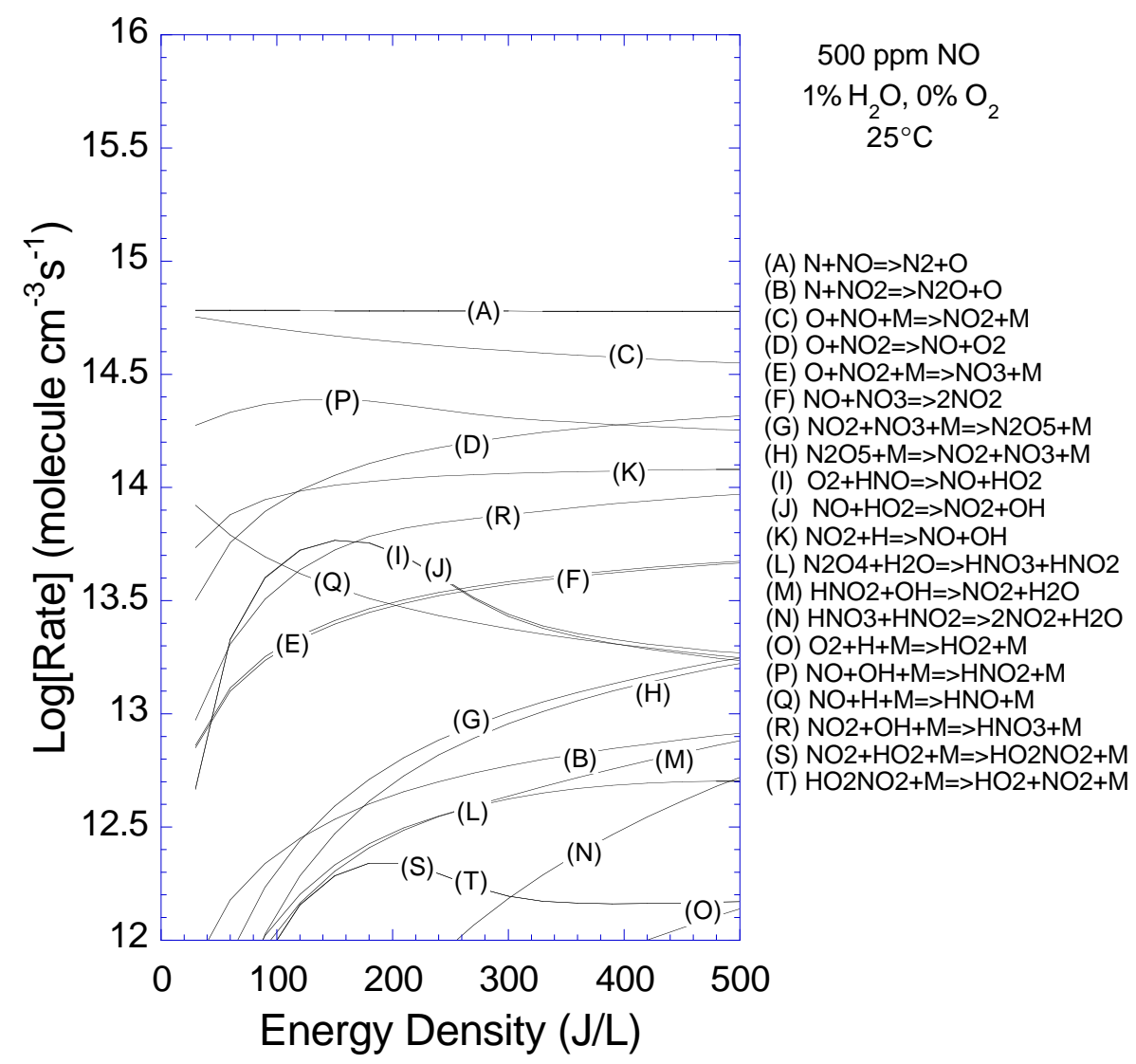

Figure 18. Chemical kinetics analysis of the important reactions during plasma processing of $500 \mathrm{ppm} \mathrm{NO}$ in $1 \% \mathrm{H}_{2} \mathrm{O}$, balance $\mathrm{N}_{2}$ at $25^{\circ} \mathrm{C}$.

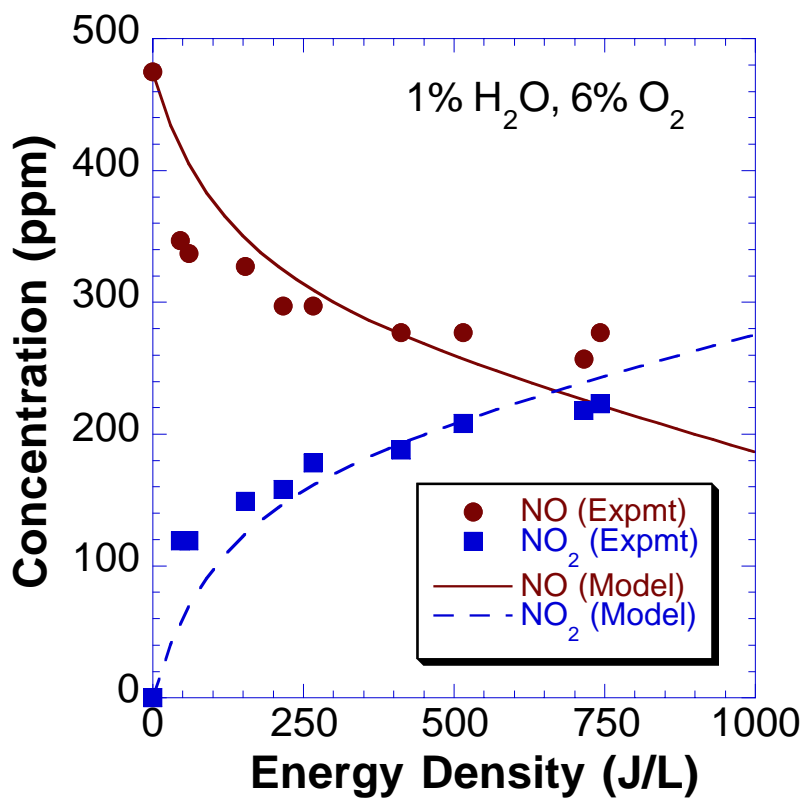

Figure 19. Plasma processing of $500 \mathrm{ppm} \mathrm{NO}$ in $1 \%$ $\mathrm{H}_{2} \mathrm{O}, 6 \% \mathrm{O}_{2}$, balance $\mathrm{N}_{2}$ at $25^{\circ} \mathrm{C}$. while the $\mathrm{H}$ radical leads to the backconversion of $\mathrm{NO}_{2}$ to NO:

$$
\mathrm{H}+\mathrm{NO}_{2} \rightarrow \mathrm{NO}+\mathrm{OH}
$$

The role of $\mathrm{H}_{2} \mathrm{O}$ becomes more significant when $\mathrm{O}_{2}$ is also present in the gas stream. Additional dissociation of $\mathrm{H}_{2} \mathrm{O}$ come from reactions with the excited state $\mathrm{O}\left({ }^{1} \mathrm{D}\right)$ :

$$
\mathrm{O}\left({ }^{1} \mathrm{D}\right)+\mathrm{H}_{2} \mathrm{O} \rightarrow 2 \mathrm{OH}
$$

Figure 19 shows the plasma processing of $500 \mathrm{ppm} \mathrm{NO}$ in $1 \% \mathrm{H}_{2} \mathrm{O}, 6 \% \mathrm{O}_{2}$, balance $\mathrm{N}_{2}$, at $25^{\circ} \mathrm{C}$. A chemical kinetics analysis of the important reactions under the same condition is shown in Figure 20. The $\mathrm{NO}$ to $\mathrm{NO}_{2}$ oxidation chemistry is the same as in the $\mathrm{NO}-\mathrm{O}_{2}-\mathrm{N}_{2}$ system. For energy densities less than $100 \mathrm{~J} / \mathrm{L}$, the $\mathrm{OH}$ is consumed in the production of nitrous acid. For energy densities greater than $100 \mathrm{~J} / \mathrm{L}$, because of the higher concentration of $\mathrm{NO}_{2}$, the $\mathrm{OH}$ radicals get consumed in the production of nitric acid:

$$
\mathrm{OH}+\mathrm{NO}_{2}+\mathrm{M} \rightarrow \mathrm{HNO}_{3}+\mathrm{M}
$$




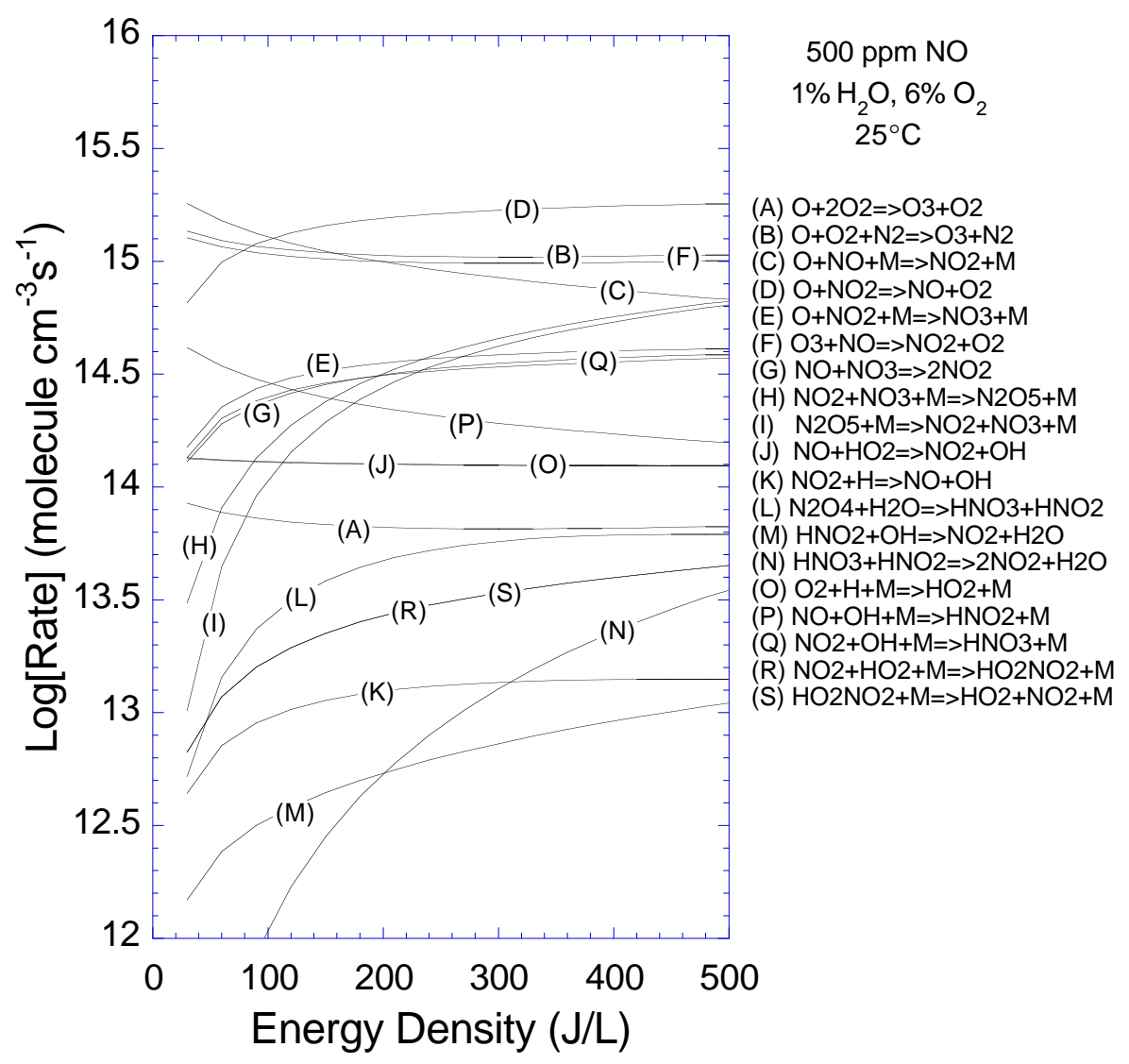

Figure 20. Chemical kinetics analysis of the important reactions during plasma processing of $500 \mathrm{ppm} \mathrm{NO}$ in $1 \% \mathrm{H}_{2} \mathrm{O}, 6 \% \mathrm{O}_{2}$, balance $\mathrm{N}_{2}$ at $25^{\circ} \mathrm{C}$.

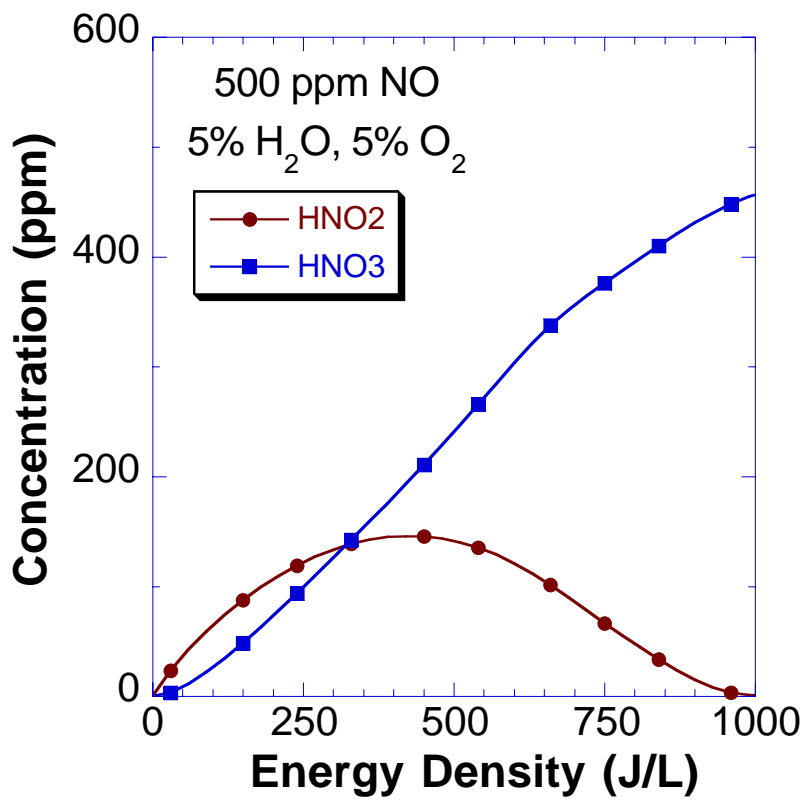

Figure 21. Formation of nitrous acid and nitric acid during plasma processing of $500 \mathrm{ppm} \mathrm{NO}$ in $5 \% \mathrm{H}_{2} \mathrm{O}$, $5 \% \mathrm{O}_{2}$, balance $\mathrm{N}_{2}$ at $25^{\circ} \mathrm{C}$.

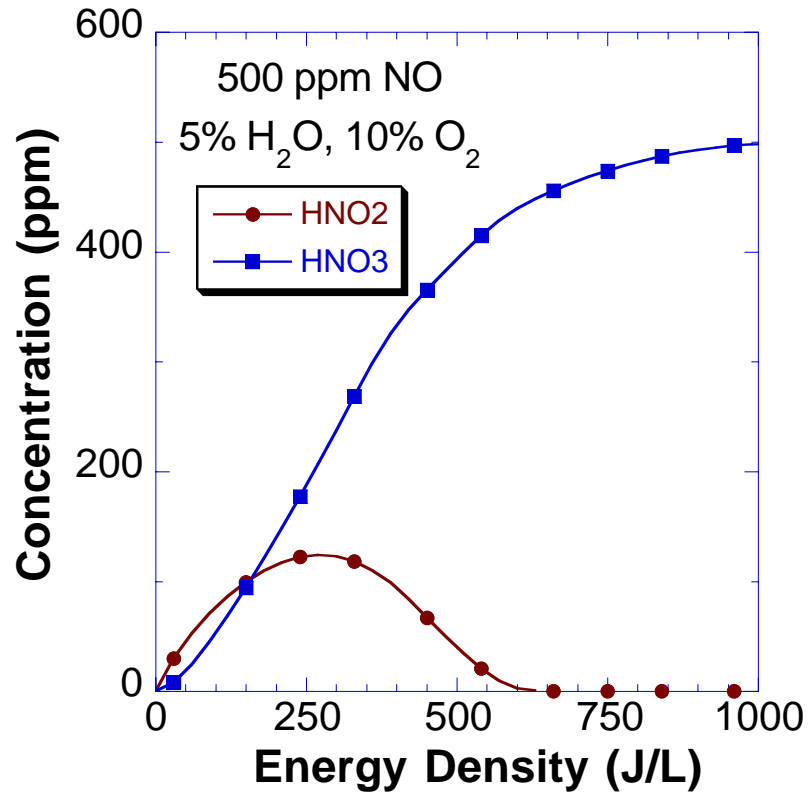

Figure 22. Formation of nitrous acid and nitric acid during plasma processing of $500 \mathrm{ppm} \mathrm{NO}$ in $5 \% \mathrm{H}_{2} \mathrm{O}$, $10 \% \mathrm{O}_{2}$, balance $\mathrm{N}_{2}$ at $25^{\circ} \mathrm{C}$. 
The role of $\mathrm{H}_{2} \mathrm{O}$ in the formation of acid products becomes more apparent when the $\mathrm{H}_{2} \mathrm{O}$ concentration is $5 \%$ and above. Figure 21 shows the nitrous acid and nitric acid concentrations during plasma processing of $500 \mathrm{ppm} \mathrm{NO}$ in $5 \% \mathrm{H}_{2} \mathrm{O}, 5 \% \mathrm{O}_{2}$, balance $\mathrm{N}_{2}$, at $25^{\circ} \mathrm{C}$. The amount of nitric acid is proportional to the amount of $\mathrm{NO}_{2}$. Figure 22 shows the nitrous acid and nitric acid concentrations during plasma processing of $500 \mathrm{ppm}$ $\mathrm{NO}$ in $5 \% \mathrm{H}_{2} \mathrm{O}, 10 \% \mathrm{O}_{2}$, balance $\mathrm{N}_{2}$, at $25^{\circ} \mathrm{C}$. As the $\mathrm{O}_{2}$ concentration is increased, the oxidation of $\mathrm{NO}$ to $\mathrm{NO}_{2}$ increases, and consequently the formation of nitric acid also increases.

\section{CONCLUSIONS}

Lean-burn gasoline and diesel engine exhausts contain a high concentration of $\mathrm{O}_{2}$. We have shown that under this condition, the dominant reaction in a plasma is the oxidation of $\mathrm{NO}$ to $\mathrm{NO}_{2}$. In the presence of $\mathrm{H}_{2} \mathrm{O}$, the $\mathrm{NO}_{2}$ can be further oxidized to nitric acid. The adsorption of acid products can easily be mistaken for chemical reduction of $\mathrm{NO}$ to $\mathrm{N}_{2}$.

The efficiency for plasma oxidation of $\mathrm{NO}$ to $\mathrm{NO}_{2}$ by means of the $\mathrm{O}$ radical is optimum at low temperatures. However, as shown in the above figures, even at low temperatures the energy density required to implement this process is still large.

Penetrante et al. $[6,11]$ have shown that hydrocarbons can enhance the oxidation of $\mathrm{NO}$ to $\mathrm{NO}_{2}$ but not the reduction of $\mathrm{NO}$ to $\mathrm{N}_{2}$. The hydrocarbons lower the electrical energy cost for oxidation of $\mathrm{NO}$ to $\mathrm{NO}_{2}$ and prevent the formation of acid products $[6,11]$. Penetrante et al [6] have also shown that when combined with an SCR catalyst, the hydrocarbon-enhanced oxidation of $\mathrm{NO}$ to $\mathrm{NO}_{2}$ in a plasma may be utilized to enhance the chemical reduction of $\mathrm{NO}_{x}$ to $\mathrm{N}_{2}$.

\section{ACKNOWLEDGMENT}

This work was performed in part at Lawrence Livermore National Laboratory under the auspices of the U.S. Department of Energy under Contract Number W-7405ENG-48, with support from the Chemical Sciences Division of the DOE Office of Basic Energy Sciences.

\section{REFERENCES}

1. Non-Thermal Plasma Techniques for Pollution Control: Part A - Overview, Fundamentals and Supporting Technologies, eds. B. M. Penetrante and S. E. Schultheis (Springer-Verlag, Berlin Heidelberg New York, 1993).

2. Non-Thermal Plasma Techniques for Pollution Control: Part B - Electron Beam and Electrical Discharge Processing, eds. B. M. Penetrante and S. E. Schultheis (Springer-Verlag, Berlin Heidelberg New York, 1993).
3. Proceedings of the 1993 Diesel Engine Emissions Research Workshop, San Diego, CA, July 19-22, 1993, Sect. IV, pp. IV-1-IV-85. (Available from the Office of Transportation Technologies, EE-32, US Department of Energy, 1000 Independence Avenue, SW, Washington, DC 20585).

4. Proceedings of the 1995 Diesel Engine Emissions Research Workshop, San Diego, CA, July 24-27, 1995, Sect. V, pp. 33-67. (Available from the Office of Transportation Technologies, EE-32, US Department of Energy, 1000 Independence Avenue, SW, Washington, DC 20585).

5. Proceedings of the 1997 Diesel Engine Emissions Research Workshop, San Diego, CA, July 28-31, 1997, Sect. III, pp. 85-163. (Available from the U.S. Department of Commerce, Technology Administration, National Technical Information Service, Springfield, VA 22161).

6. Penetrante, B. M., Brusasco, R. M., Merritt, B. T., Pitz, W. J., Vogtlin, et al.., "Plasma-Assisted Catalytic Reduction of NOx", SAE Paper 982508 (1998).

7. Manley, T. C. , "The Electrical Characteristics of the Ozonator Discharge”, Trans. Electrochem. Soc. 84, 83 (1944).

8. Morgan W. L. and Penetrante, B. M., "ELENDIF: A Time-Dependent Boltzmann Solver for Partially Ionized Plasmas", Comp. Phys. Comm. 58, 127-152 (1990).

9. Kee, R. J., Rupley F. M. and Miller, J. A., "ChemkinII: A FORTRAN Chemical Kinetics Package for the Analysis of Gas Phase Chemical Kinetics," Sandia National Laboratories Report No. SAND89-8009B UC-706 (April 1992).

10. Penetrante, B.M., Hsiao, M.C., Merritt, B.T., Vogtlin, G.E., Wallman, P.H., Kuthi A., Burkhart, C.P., and Bayless, J.R., "Electron-Impact Dissociation of Molecular Nitrogen in Atmospheric-Pressure NonThermal Plasma Reactors", Appl. Phys. Lett. 67 , 3096 (1995).

11. Penetrante, B. M., Pitz, W. J., Hsiao, M. C., Merritt, B. T. and Vogtlin, G. E., "Effect of Hydrocarbons on Plasma Treatment of NOx", in Proceedings of the 1997 Diesel Engine Emissions Research Workshop, San Diego, CA, July 28-31, 1997, pp. 123-128. (Available from the U.S. Department of Commerce, Technology Administra-tion, National Technical Information Service, Springfield, VA 22161). 